\title{
Cost of root disease on white clover growth in New Zealand dairy pastures
}

\author{
S.A. Wakelin ${ }^{1}$ - Y. Eslami ${ }^{2}$ - K. Dake ${ }^{3}$ B.E.A. Dignam ${ }^{1,4}$ - M. O'Callaghan ${ }^{1}$
}

Received: 17 December 2015 / Accepted: 19 April 2016/Published online: 23 April 2016

(C) The Author(s) 2016. This article is published with open access at Springerlink.com

\begin{abstract}
The cost to clover growth of soil-borne root disease was measured in ten New Zealand dairy pasture soils. The average increase clover growth (weight) after soil pasteurisation was $28.5 \%$, but ranged from a $64 \%$ increase (Whataroa soil) to a decrease of $11.9 \%$ (Ruakura soil). The economic cost of reduced clover growth was determined using the Farmax Dairy Pro decision support system. In Southland and Canterbury, clover root disease was estimated to cost $\$ 750$ and $\$ 715 \mathrm{ha}^{-1}$ year $^{-1}$ respectively, and in the Waikato region $\$ 1506 \mathrm{ha}^{-1}$ year $^{-1}$. DNA-based testing of the soils detected the presence of diverse fungal, oomycete and nematode pathogen populations. A significant linear relationship was found between reduction in clover growth and group $\mathrm{F}$ Pythium spp. $(P=0.0177)$. The DNA-based assay indicated that Aphanomyces trifolii, a root pathogen of subterranean clover, may be present in the dairy-pasture soils. As this pathogen is currently not recognised as present in New Zealand, a definitive determination of its presence is required. Based on the high economic costs of diseases, the control of soil-borne root pathogens in New Zealand pasture is a direct means to increase profitability.
\end{abstract}

S.A. Wakelin

Steve.Wakelin@AgResearch.co.nz

1 AgResearch Ltd, Lincoln Science Centre, Private Bag, Christchurch 4749, New Zealand

2 Agricultural and Life Sciences Division, Lincoln University, PO Box 84, Lincoln, New Zealand

3 Agriculture International Ltd, South New Brighton, Christchurch 8062, New Zealand

4 Bio-Protection Research Centre, Lincoln University, PO Box 85084, Canterbury 7647, New Zealand
Keywords Pythium - Clover root disease $\cdot$ Economic cost . Pasture $\cdot$ Aphanomyces trifolii

\section{Introduction}

A diverse range of pathogens are known to cause disease on the roots of forage plants in New Zealand pastures (Harvey and Harvey 2009). These include nematodes, fungi, and Oomycetes (Falloon 1985; Skipp and Christensen 1989; Waipara et al. 1996; Watson and Mercer 2000; Sarathchandra et al. 2000), which vary from highly host-specific through to broad-range generalists. In most cases, however, root diseases are often caused by a suite (disease complex) of pathogens (Skipp and Watson 1996). For example, disease maybe initiated through infection of the root tissue by a virulent hostadapted species, with subsequent colonisation of the compromised tissue by a range of secondary (generalist) pathogens.

Although the importance of soil borne disease to pasture productivity is widely recognised, there has been relatively little fundamental or applied research effort aimed at understanding or controlling disease complexes. In New Zealand, the bulk of research efforts were conducted in the mid 1980's through to the early 2000's (Falloon 1985; Skipp and Christensen 1989; Waipara et al. 1996; Watson and Mercer 2000; Sarathchandra et al. 2000), with relatively little work conducted for the past 15 years. This is at odds with the trend for increased value of pasture production on a per hectare basis. In the 1990's, the export value of pasture production in New Zealand was approximately $\$ 585$ per ha (Statistics New Zealand 1999). This has grown to the current level of $\$ 2007$ per ha, a nearly $241 \%$ increase (Ministry of Primary Industries 2013). A portion of this increase can be attributed to land use conversion from sheep and beef grazing to dairy. In the period between 1990 and 2014, the area used for dairy 
pasture grew from 1.57 million ha to 2.42 million ha (Statistics New Zealand 1999, 2014). However, the direct value of dairy as a land use has also grown, with total export values of $\$ 2.98$ billion in 1996 from 1.76 million ha, to $\$ 15.82$ billion in 2014 from 2.42 million ha.

The high return per ha of dairying (export value of $\sim \$ 6500$ per annum; 2014 data calculated from above values) is an outcome of high inputs (costs) of fertilisers, irrigation of dryland areas to escape summer drought conditions (e.g. Canterbury), close management of pasture weeds and pests, and many other factors. As such, there is an urgent need to define the base-line of soil biological constraints to pasture production. Furthermore, by determination of the economic cost of root diseases, appropriate decisions can be made for prioritisation of areas for research and development. This also provides an economic base (value proposition) for decisions associated with on-farm control of soil-borne diseases.

The maintenance of clover in pastures is central to the profitability and sustainability of New Zealand's pasture systems (Caradus et al. 1996). Clovers provide biological nitrogen fixation into pasture soils, thus lifting total system fertility and productive capacity (Ledgard 2001), and have high forage quality (nutritive value and intake characteristics) (Harris et al. 1997). Thus the value of clover for milk production in New Zealand is unequivocal (Woodfield and Clark 2009).

The aim of this work was to determine the magnitude of soil biological constraints to pasture production, with a focus on clover within dairy-based systems. Given the relatively high value of dairy-based pastoral land use, we aimed to calculate a conservative economic cost of root diseases to system profitability. As dairying is intensively managed, and typically conducted on accessible terrain, this land use provides greater opportunity for disease control than hill or high country pastoral systems (Dignam et al. 2016). As such, dairy-based production is best positioned to provide disease management practices to reduce soil biological constraints to pasture production. This is directly in line with industry-led targets to "lift production while reducing the environmental impacts of dairy farming' (DairyNZ 2009). Alleviation of soil biological constraints (i.e. reduction of pathogens or supply of beneficial symbionts) is identified as a key path towards achieving this goal (Wakelin et al. 2013).

\section{Materials and methods}

\section{Soil collection and handling}

Soils were collected from 10 dairy farms across a broad geographic range. The sites are listed in Table 1. Approximately $12 \mathrm{~kg}$ of soil was collected from a single paddock at each site. Sampling was made to the approximate rooting depth of the pasture $(\sim 10-15 \mathrm{~cm})$. On return to the laboratory, the samples were sieved to $2 \mathrm{~mm}$ (removing stones and other bulky material) and stored at $4{ }^{\circ} \mathrm{C}$ until use. Soil physicochemical properties were determined at Hill Laboratories Ltd. (Christchurch), using well characterised methods (e.g. as described in Wakelin et al. 2013).

For each soil, the moisture content was determined using loss of mass (water) after drying a sample at $105^{\circ} \mathrm{C}$ for $24 \mathrm{~h}$ $\left(\theta_{d}\right)$; soils that were $>40 \%$ moisture were air-dried until this level was obtained. The maximum water holding capacity (MWHC) of each soil was determined by calculating the mass of water hold under gravity (i.e. no suction; Jenkinson and Powlson 1976).

\section{Disease release assay}

The growth of white clover (Trifolium repens) was assessed in non-sterilised and sterilised soils. For each soil, $1 \mathrm{~kg}$ (dry weight equivalent) of soil (at $40 \% \theta_{\mathrm{d}}$ ) was weighed into 8 polyethylene bags. Four of these bags were microwave irradiated for $4 \mathrm{~min}$ at $850 \mathrm{~W}$. While these are hereafter referred to as 'sterilised' experimental treatments, it is highly likely the soil was pasteurised to an extent and certainly colonised by microorganisms over time. The remaining four bags of soil were not treated (non-sterilised).

For both sterile and non-sterile treatments, 24 small pots were set up with $130 \mathrm{~g}$ soil (dry wt) in $65 \mathrm{~mm}$ diameter plastic (non-draining) disposable cups. Ten seeds of white clover (cv. Tribute) were placed on the surface and covered with a further $20 \mathrm{~g}$ of soil. The samples, in replicates of 6 pots, were then brought to $80 \%$ of the MWHC using either water $(0 \times$ fertiliser $)$, 'Thrive' all-purpose soluble fertiliser (Yates, NZ) at $0.22 \mathrm{~g} \mathrm{l}^{-1}$ $(1 \times$ fertiliser $)$, double-rate Thrive $(2 \times$ fertiliser $)$, or triple-rate Thrive $(3 \times$ fertiliser). The pots were placed in a controlled environment room $\left(12 \mathrm{~h}\right.$ photoperiod; $\left.20^{\circ} \mathrm{C}\right)$. Pots were maintained at $80 \%$ MWHC by addition of water or soluble fertiliser to the respective treatments. After 6 weeks, the clover plants in each pot were excised at their base (soil level) and the fresh weight per pot immediately determined.

\section{DNA isolation and pathogen testing}

Samples of soil were sent to the root disease testing service (RDTS; Primary Industries and Regions SA; PIRSA, Australia) for pathogens DNA detection (Ophel-Keller et al. 2008). This service involves the extraction of DNA from bulk samples of soil, and qPCR-based detection of a suite of pathogenic taxa in the samples. This included fungi (Didymella pinodes, Rhizoctonia solani AG groups 2.1, 2.2, and 8), Oomycetes (Pythium clades F and L, Phytophthora clandestina, Aphanomyces trifolii), and nematode pathogens (Pratylenchus neglectus, Pr. penetrans, and Pr. quasitereoides). Details associated with these DNA tests are given in Simpson et al. (2011). 
Table 1 Soils: origin, soil type, and physicochemical properties

\begin{tabular}{|c|c|c|c|c|c|c|c|c|c|}
\hline Site & Soil type ${ }^{\mathrm{a}}$ & $\mathrm{pH}$ & $\begin{array}{l}\text { Olsen } \\
\text { phosphorus }^{\text {b }}\end{array}$ & $\begin{array}{l}\text { Sulphate } \\
\text { sulphur }\end{array}$ & Nitrate- $\mathrm{N}^{\mathrm{c}}$ & $\begin{array}{l}\text { Total } \\
\text { nitrogen }^{\mathrm{d}}\end{array}$ & $\mathrm{CEC}^{\mathrm{e}}$ & $\begin{array}{l}\text { Total base } \\
\text { saturation }^{\mathrm{d}}\end{array}$ & $\begin{array}{l}\text { Volume } \\
\text { weight }^{\mathrm{f}}\end{array}$ \\
\hline Taieri & Gley & 7.2 & 92 & 36 & 44 & 0.37 & 24 & 100 & 0.91 \\
\hline Kurow & Recent & 6.3 & 12 & 4 & 38 & 0.31 & 15 & 77 & 1.01 \\
\hline Inchbonnie & Recent & 5.6 & 29 & 13 & 34 & 0.28 & 14 & 44 & 0.91 \\
\hline Gordonton & Organic (peat) & 5.5 & 57 & 44 & 121 & 1.68 & 81 & 55 & 0.54 \\
\hline Rotorua & Allophanic & 5.7 & 8 & 13 & 16 & 0.44 & 15 & 29 & 0.74 \\
\hline Eyrewell & Brown & 6.1 & 24 & 50 & 72 & 0.17 & 13 & 71 & 1.02 \\
\hline Whataroa & Recent & 5.3 & 30 & 23 & 33 & 0.32 & 15 & 36 & 0.75 \\
\hline Springston & Gley & 6.1 & 45 & 35 & 52 & 0.49 & 30 & 79 & 0.81 \\
\hline Ruakura & Podzol & 6.3 & 26 & 75 & 72 & 0.69 & 31 & 66 & 0.72 \\
\hline Woodlands & Brown & 6 & 35 & 19 & 31 & 0.47 & 20 & 58 & 0.83 \\
\hline
\end{tabular}

${ }^{\mathrm{a}}$ New Zealand soil classification order (Hewitt 1988), ${ }^{\mathrm{b}} \mathrm{mg} / \mathrm{L},{ }^{\mathrm{c}} \mathrm{mg} / \mathrm{kg},{ }^{\mathrm{d}} \%$, ${ }^{\mathrm{e}}$ cation exchange capacity in me/100 g, ${ }^{\mathrm{f}} \mathrm{g} / \mathrm{ml}$

\section{Analysis of data}

Disease pressure in the soils was calculated based on the percentage difference in plant growth (fresh weight; fwt) between the sterilised (microwave pasteurised) and non-sterilised soils:

$\%$ growth change

$$
=\frac{(f w t \text { plants sterile soil })-\left(f w t \text { plants } \text { non }^{-} \text {sterile soil }\right)}{f w t \text { plants sterile soil }} \times 100
$$

For each soil, the influence of sterilisation on plant growth was tested using t-tests (two tailed). Each soil was tested individually (i.e. we did not assume consistent variance among the soils), and corrections were made for multiple comparisons using the Holm-Š́iák method (Holm 1979) at $\alpha=0.05$. The average disease pressure across the ten soils was calculated and linear regression used to determine if relationships existed to soil physiochemical properties or soil pathogen levels (RDTS pathogen - DNA quantification).

The potential influence of nutrient mobilisation (following soil sterilisation) on increased clover growth was assessed by response of plants to soluble fertiliser addition. For each soil, the plant growth across the four fertiliser levels was assessed in the sterile and non-sterile soil using linear regression. Within each soil, the sterile and non-sterile fertiliser responses (slope of regression lines) were tested for response to fertiliser addition, and then for then for equality of responses (i.e. response of fertiliser addition in non-sterile soil $\neq$ to response in sterile soil). This was conducted by comparing slopes of the linear regressions (twotailed t-test), with the null hypothesis that the slopes were parallel. A description of the rationale is given in the discussion.

Relationships between pathogen abundance values and soil disease were explored using linear regression. Each of the above analyses was performed in Prism7 (GraphPad Software Inc., CA).

\section{Economic modelling of clover disease cost}

Production and financial costs of clover soil disease were analysed using Farmax Dairy Pro decision support models (Bryant et al. 2010) of the Southland, Canterbury, and Waikato-BOP Monitor Dairy farms of Year 2012/13. The model assumed that removing clover soil disease constraints would increase average clover yield by $28.5 \%$. In turn, this would impact ryegrass-clover pasture yield, seasonally adjusted pasture metabolisable energy (ME), clover-rhizobia $\mathrm{N}_{2}$ fixation, and milk solid production. From these, effects on farm revenue, expenditure, and gross margin were calculated.

Underlying data in the models were based on appropriate Ministry of Agriculture and Fisheries MAF/ Ministry of Primary Industries monitor farms for each region. Pasture growth profiles and clover content were determined from Woodlands and Mona Bush (representing Southland), Lincoln and Winchmore (representing Canterbury), and Tirau and Ruakura (representing Waikato). DairyNZ farm expenses, milk price and levy costs for year 2012/13 were used. $\mathrm{N}$ fertiliser use, and feed supplementation were based on best practice for the regions, and the models considered stock wintered with complete reconciliation of stock for the year.

Models required that monthly pasture cover on the farm should exceed minimum pasture cover to ensure feed intake and pasture quality meets desired livestock numbers and performance. From this, scenarios for each region were generated that encompassed change of stock rate wintered at a maximum feasible level (current farm potential). Each of these were then adjusted to account for an additional $28.5 \%$ increase in clover growth (fresh weight). The cost of clover root disease was taken as the difference between the scenarios for each respective region. 


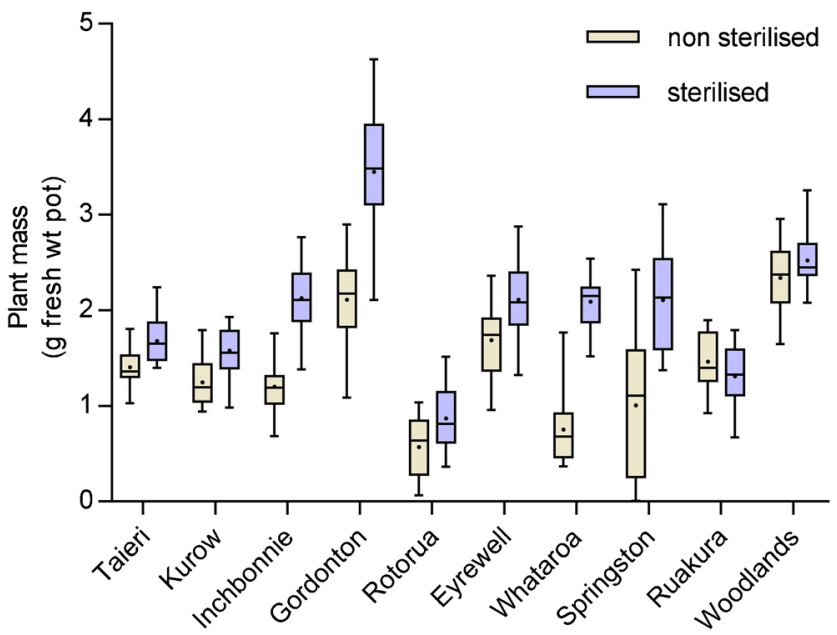

Fig. 1 Clover growth in ten microwave sterilised and non-sterile soils. Boxes extend from the 25th to 75th percentiles and whiskers from the smallest to the largest values. The solid line indicates the median value and the floating '•' symbol the mean

\section{Results}

\section{Clover disease pressure in dairy soils}

Sterilisation of soils significantly $(P<0.05)$ increased clover growth in all soils except for Ruakura (Fig. 1). When calculated as percentage growth change, microwave-treatment of soil resulted in clover growth increases from $64 \%$ (Whataroa) to -11.9 (Ruakura). An average 'disease pressure' of $+28.55 \%$ was calculated across the 10 soils, and this value was used for the economic modelling for each of the three regional scenarios.

\section{Influence of soluble fertiliser on plant growth in sterile and non-sterile soils}

Linear regression was used to determine relationships between fertiliser addition and soil sterilisation on clover growth. The regression slope summary data are given in Table 2. With the exception of soil from Eyrewell, the responses to fertiliser addition between the sterile and non-sterile soils were not different $(P>0.05$; Table 2$)$. There was no evidence that nutrient released from the sterilisation process significantly contributed to the plant response between the sterile and non-sterile treatments. For the Eyrewell soil, there was no fertiliser response in the non-sterile soil, however, in the sterile soil there was $(P<0.001)$.

\section{Soil pathogens}

A DNA-based test was used to detect for the presence of a suite of pathogens in the pasture soils; the set of species in which positive DNA-based tests were found are given in Fig. 2a. Across these, positive DNA-based 'detection' of multiple fungal and Oomycete pathogens were found in most soils (Fig 2a). However, the most commonly detected pathogen was Pythium clade F, with positive results returned for all soil samples. Rhizoctonia solani AG2.1 and 2.2 were mutually exclusive among the soils (correlation $r=-0.68 ; P=0.029$ ), with the exception of Ruakura where both were present. The nematode species Pratylenchus neglectus and Pr. penetrans had sparse occurrence among the soils, while Pr. quasitereoides and Pr. thornei were not detected. The pathogenic fungi Didymella pinodes, Rhizoctonia solani AG8, and the Oomycete Phytophthora clandestina (Fig 2a), were not detected in the dairy pasture soils. Aphanomyces trifolii, a relatively recently
Table 2 Clover response to fertiliser addition in sterile and non-sterile soils. All data are probability estimates from linear regression

\begin{tabular}{|c|c|c|c|c|c|}
\hline \multirow[t]{2}{*}{ Soil } & \multicolumn{2}{|c|}{ Regression slope } & \multicolumn{2}{|c|}{ Test for slope $\neq 0$} & \multirow{2}{*}{$\begin{array}{l}\text { Test for } \\
\text { equal slopes }\end{array}$} \\
\hline & Non-sterile & Sterile & Non-sterile & Sterile & \\
\hline Taieri & 0.065 & 0.018 & 0.058 & 0.669 & 0.364 \\
\hline Kurow & 0.063 & 0.120 & 0.152 & 0.003 & 0.306 \\
\hline Inchbonnie & 0.039 & -0.024 & 0.412 & 0.713 & 0.431 \\
\hline Gordonton & -0.016 & -0.228 & 0.853 & 0.065 & 0.155 \\
\hline Rotorua & 0.161 & 0.172 & 0.003 & 0.001 & 0.866 \\
\hline Eyrewell & -0.085 & 0.239 & 0.189 & $<0.001$ & $<0.001$ \\
\hline Whataroa & -0.063 & -0.033 & 0.381 & 0.523 & 0.745 \\
\hline Springston & -0.054 & -0.023 & 0.587 & 0.865 & 0.847 \\
\hline Ruakura & 0.050 & -0.052 & 0.350 & 0.380 & 0.199 \\
\hline Woodlands & 0.159 & 0.046 & 0.009 & 0.358 & 0.135 \\
\hline
\end{tabular}

Values in bold-type are significant at $P<0.05$ 
described multi-host root-rot pathogen (O’Rourke et al. 2010), was detected in 7 of the 10 soils (Fig 2a).

For each of the pathogens, regressions were made between abundance (DNA quantification) and clover growth reduction across the soils. A significant positive association was found between abundance of Pythium clade F pathogens and clover disease pressure $\left(P=0.0177 ; \mathrm{R}^{2}=0.525\right)$; this relationship is shown in Fig. 2b. Disease pressure was not positively related $(P<0.05)$ to the occurrence of any of the other pathogens detected.

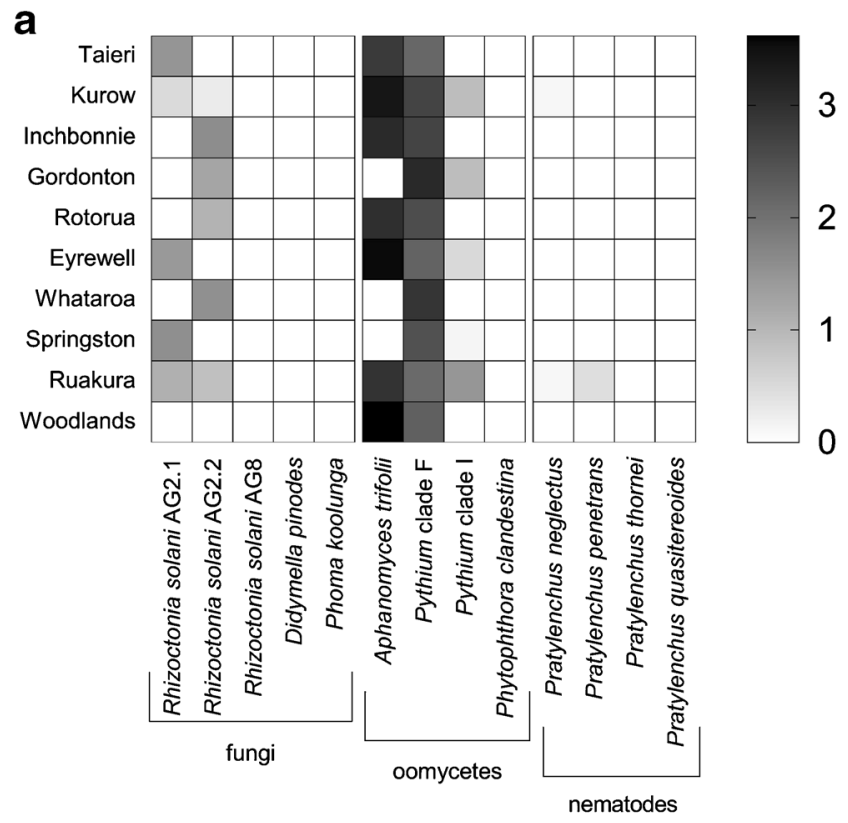

b

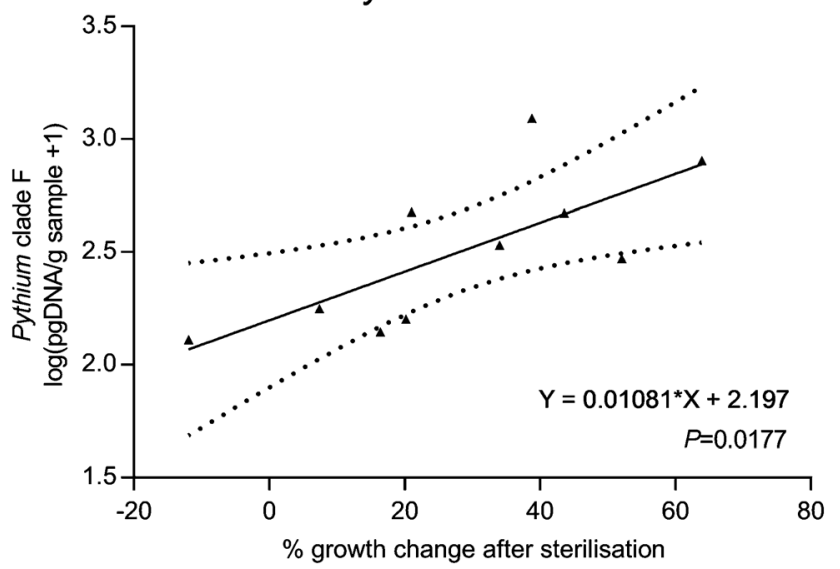

Fig. 2 a Heat-map of soil DNA testing for pathogenic fungi, oomycetes, and nematodes. All fungi and oomycete data were pg DNA detected/g sample, except for Aphanomyces trifolii (copies/g sample). Nematodes are given as counts/g soil. All data were log-transformed. Several pathogens were not detected ( 0 -values). b Relationship between clover growth after soil sterilisation (release from disease pressure) and quantity of Pythium clade f DNA. Solid line is the linear regression (equation given) and dashed lines the $95 \%$ confidence intervals

\section{Economic modelling of clover disease cost}

Economic cost of soil disease on clover growth was determined separately for the Canterbury, Southland, and Waikato regions, as each has varying seasonal pasture growth rates, percentage clover composition, and input costs. In Southland and Canterbury the costs of root disease to potential production were similar, at $\$ 750$ and $\$ 715 \mathrm{ha}^{-1}$ year $^{-1}$ respectively, but were much greater in the Waikato at $\$ 1506 \mathrm{ha}^{-1}$ year ${ }^{-1}$.

\section{Discussion}

The average disease pressure in New Zealand's dairy soils is estimated to cost $28.5 \%$ of clover growth, however, this is variable and can exceed $60 \%$ growth in some soils (e.g. Whataroa). These are slightly lower than estimates of pasture production losses of 40-50\% based on a consensus of studies (Skipp and Watson 1996) but reflect that the focus of this study was solely on clover. Furthermore, the estimates of disease pressure in the assays conducted are conservative. Pasteurisation of the soil not only removes deleterious microorganisms, but also beneficial taxa that are required to support plant growth. Notably, these include Rhizobium bacteria (Nfixing symbionts of clover) and mycorrhizal fungi. Indeed, in the absence of significant disease pressure, pasteurisation of soil can be expected to have no direct benefit (as measured in Ruakura soil) or a nett negative effect (removal of beneficial symbionts) on plant health. Regardless, our findings reinforce the high burden that soil biological constraints have on clover growth in New Zealand's pastoral systems, and the urgent need to be able to accurately assess pathogen populations and predict and manage disease, particularly in high-input, high-value pastoral systems.

The disease burden on clover has implications for potential productivity of the pastoral systems. On a per hectare basis, the highest cost of disease was in the Waikato region with the reduction in clover growth estimated to cost $\$ 1506$ to potential gross margins per year. In Canterbury and Southland, these margins were approximately half that of Waikato, yet still represent a very large potential loss in the farming systems. By establishing these base line costs, and appreciating that they are ongoing in perennial systems, an accurate value proposition associated with control of these diseases is evident.

In addition to a direct cost on plant productivity, rootdisease pressure also contributes indirect costs associated with reduced nutrient and water-use efficiency (Baligar et al. 2001; Angus and Van Herwaarden 2001; Angus et al. 2015). However, much of the work conducted in this area has been in arable cropping systems, and the indirect cost of root disease on nutrient and water use efficiency in pastoral systems 
represents a significant knowledge gap (Unkovich 2012). For pasture legumes, such as white clover, these costs may be particularly high when root nodules are diseased, resulting in reduced biological nitrogen fixation and greater requirement to access N from the soil mineral N pool (Unkovich 2012).

Pythium clade F contains a group of highly virulent plant pathogens with worldwide distribution, such as $P$. irregulare and P. debaryanum (Lévesque and de Cock 2004). Indeed, both species have been recorded as agricultural pathogens in New Zealand (Robertson 1973; Falloon 1985; Waipara and Hawkins 2000), along with other pathogenic species such as P. ultimum (Robertson 1973; Falloon 1985). The association found between clade F Pythium and clover disease is supported by work in Australia. Using the same detection system, Simpson et al. (2011) found the DNA concentration of clade F Pythium to have a linear relationship with damage to Trifolium subterraneum (subterranean clover) across multiple sites in Australia. This reinforces the importance of these pathogens in limiting production in pastoral agroecosystems.

Plant pathogenic Pythium spp. often have a broad host range, causing diseases ranging from asymptomatic root invasion to highly devastating damping-off root rot (Christensen et al. 1988; Falloon 1985), and often infect plants as multiplepathogen disease complexes (e.g. Barbetti et al. 1987; Skipp and Watson 1987, 1996). As shown in this study, the control of these pathogens is highly desirable as it may significantly increase the productive capacity of agroecosystems. However, these attributes also make Pythium very difficult to control. In pastoral systems in particular, options for chemical control are currently limited to seed dressings (soil drenches being costly for broad-acre application), and plant breeding has yet to provide robust heritable resistance traits. However, the development of disease-suppressive soils offers one of the few approaches whereby gains in reducing disease in pastures may be achieved (Dignam et al. 2016). The application of DNA based tools that can quantify the pathogen loading in soils over time will be an important component of this approach (Dignam et al. 2016). In addition, by monitoring pathogen populations during changes in farm management, e.g. shift in stocking rate, alteration of fertiliser inputs, or change of pasture composition, insights in to the ecology of the pathogens in farming systems can be gained, and potential opportunities to control population sizes identified (Dignam et al. 2016).

The low levels of detection of the nematode species was not surprising. Many of these are primarily pathogenic to cereal crops and are included as part of the DNA-based pathogen testing provided to grain growers in southern Australia (Simpson et al. 2011). While some of the Pratylenchus spp. are present in New Zealand, they are of low abundance and importance in pasture systems. Pratylenchus quasitereoides a cereal pathogen described from Western Australia (Hodda et al. 2014) is not present in New Zealand. The nematode taxa of greatest destructive potential in New Zealand pasture systems are species of Meloidogyne (Watson and Mercer 2000). There is currently no DNA-based testing service to quantify populations of these in New Zealand pastures. Similarly, the lack of detection of the fungal pathogens Rhiocotonia solani AG8, Didymella pinodes, and Phoma koolunga in these samples was not surprising. $R$. solani AG8 is of primary importance in grain cereal systems, while Phoma koolunga and Didymella pinodes are involved in the Aschochyta-blight disease-complex of field pea (Davidson et al. 2009).

An unexpected finding was the detection of Aphanomyces trifolii DNA in all of the pasture samples tested. This Oomycete pathogen was recovered from diseased subterranean clover roots in Western Australia, and was subsequently found to be cause root rot on a wide range of plant species (O'Rourke et al. 2010). As A. trifolii has not been reported in New Zealand, the detection of this significant pathogen in this study has important implications. If the presence of the pathogen is validated, it will remain to be determined if it has recently invaded New Zealand or has been established for some time or is indigenous. The potential host-range of the pathogen is unknown, however, testing to date (O'Rourke et al. 2010) indicates strong pathogenicity to the forage legumes T. subterraneum, Medicago polymorpha, and Medicago truncatula. The pathogenicity of $A$. trifolii to forage legumes of importance to New Zealand, particularly T. repens, T. pratense, and M. sativa requires determination.

A concern when using soil pasteurisation (or sterilisation) to remove the biological background is the flush of nutrients that can occur through mineralisation of the microbial biomass (Jenkinson and Powlson 1976). Although these are immobilised as the microflora rapidly establishes, the early provision of nutrients to the seedling may account for some of the growth promotion observed in the sterilised treatments. An approach to address this is the use of a fertiliser doseresponse treatment within both the sterile and non-sterile treatments, and the comparison of the fertiliser responses therein (Skipp and Sarathchandra 1999). However, we found no evidence that nutrient release from soil sterilisation contributed to the stimulation of clover growth (Table 2). As noted previously, in this study the context of 'sterilisation' is primarily in relation to alleviation of pathogen loads, and the soil microbiology can be more reasonably considered as 'pasteurised'. In such systems, we expect a rapid re-colonisation of the soil microbiota and immobilisation of nutrients which may have been plant-available (Jenkinson and Powlson 1976). This supports the findings of Skipp and Sarathchandra (1999), the 'microwaved soil pathogen potential assay', is not sensitive to the influence of nutrient release from the soil treatment.

Based on these findings, three primary recommendations can be made. Firstly, root diseases are causing a significant economic cost to farmers. Given the high costs and return of modern pastoral agriculture, research into identifying the 
primary causal agents (and complexes) is needed as a basis to developing control options. Secondly, diagnostic tools such as DNA-based disease testing assays are required to establish the potential disease pressure in farming systems. Combined with modelling (such as described here), these can be used to enable informed decision making on the cost-return of disease control using various measures (chemical, cultural, or biological). Thirdly, there is currently no widespread monitoring of potential incursion of new soil-borne pathogens into New Zealand pastures that impose an additional direct burden on production and also reduce the efficiency of inputs of water and fertiliser.

Acknowledgments At AgResearch Ltd., Richard Townsend helped in the collection of soils, Dawn McMillan assisted with data and literature searching, and Nigel Bell and Lee Aalders provided information on nematode species representing important pathogens in NZ pastures. John Caradus and Bruce Belgrave (Grasslanz Technology Ltd) provided useful references associated with white clover seed production. Alan McKay and the team pasture pathology team at SARDI assisted with soil transfer and DNA testing to PIRSA Adelaide. We thank the journal editor and an anonymous reviewer for their time and thoughtful consideration reviewing this manuscript. This work was partially supported by through the New Zealand MBIE and DairyNZ funded programme "Improving forage legume -rhizobia performance" (C10X1308).

Open Access This article is distributed under the terms of the Creative Commons Attribution 4.0 International License (http:// creativecommons.org/licenses/by/4.0/), which permits unrestricted use, distribution, and reproduction in any medium, provided you give appropriate credit to the original author(s) and the source, provide a link to the Creative Commons license, and indicate if changes were made.

\section{References}

Angus JF, Van Herwaarden AF (2001) Increasing water use and water use efficiency in dryland wheat. Agron J 93:290-298

Angus JF, Kirkegaard JA, Hunt JR, Ryan MH, Ohlander L, Peoples MB (2015) Break crops and rotations for wheat. Crop Pasture Sci 66: $523-552$

Baligar VC, Fareria NK, He ZL (2001) Nutrient use efficiency in plants. Commun Soil Sci Plant Anal 37:921-950

Barbetti MJ, Sivasithamparam K, Wong DH (1987) Fungicidal drenches for control of root rot in subterranean clover. Plant Soil 101:151-157

Bryant JR, Ogle G, Marshall PR, Glassey CB, Lancaster JAS, García SC, Holmes CW (2010) Description and evaluation of the Farmax dairy pro decision support model. N Z J Agric Res 53:13-28

Caradus JR, Woodfield DR, Stewart AV (1996) Overview and vision for white clover. Agronomy society of NZ special publication no 11. Grassl Res Pract Ser 6:1-6

Christensen MJ, Falloon RE, Skipp RA (1988) A Petri plate technique for testing pathogenicity of fungi to seedlings and inducing fungal sporulation. Australas Plant Pathol 17:45-47

DairyNZ, (2009) The strategy for New Zealand dairy farming 2009/2020 www.dairynz.co.nz/file/fileid/16856

Davidson JA, Hartley D, Priest M, Krysinska-Kaczmarek M, Herdina MKA, Scott ES (2009) A new species of Phoma causes ascochyta blight symptoms on field peas (Pisum sativum) in South Australia. Mycologia 101:120-128
Dignam B, O’Callaghan M, Condron L, Raaijmakers J, Kowalchuk G, Wakelin S (2016) Challenges and opportunities in harnessing soil disease suppression for sustainable pasture production. Soil Biol Biochem. (accepted for publication)

Falloon RE (1985) Fungi pathogenic to ryegrass seedlings. Plant Soil 86: $79-86$

Harris SL, Clark DA, Auldist MJ, Waugh CD, Laboyrie PG (1997) Optimum white clover cotent for dairy pastures. Proc N Z Grassl Assoc 59:29-33

Harvey IC, Harvey BM (2009) Pasture diseases in New Zealand. BioProtection Research Centre, Lincoln, New Zealand, 144 pp

Hewitt AE (1988) New Zealand soil classification. Lincoln, New Zealand. Manaaki Whenua Press

Hodda M, Collins SJ, Vanstone VA, Hartley D, Wanjura W, Kehoe M (2014) Pratylenchus quasitereoides $\mathrm{n}$. Sp. from cereals in Western Australia. Zootaxa 3866:277-288

Holm S (1979) A simple sequentially rejective multiple test procedure. Scand J Stat 6:65-70

Jenkinson DS, Powlson DS (1976) The effects of biocidal treatments on metabolism in soil - V. A method for measuring soil biomass. Soil Boil Biochem 8:209-213

Ledgard SF (2001) Nitrogen cycling in low input legume-based agriculture, with emphasis on legume/grass pastures. Plant Soil 228:43-59

Lévesque CA, de Cock WAM (2004) Molecular phylogeny and taxonomy of the genus Pythium. Mycol Res 108:1363-1383

Ministry of Primary Industries (2013) Table 2. Merchandise export revenue, June quarter 2013 and June year 2013, in primary industries production and trade june quarter 2013. Wellington, New Zealand: Ministry of Primary Industries

O'Rourke TA, Ryan MH, Li H, Ma X, Sivasithamparam K, Fatehi J, Barbetti MJ (2010) Taxonomic and pathogenic characteristics of a new species Aphanomyces trifolii causing root rot of subterranean clover (Trifolium subterraneum) in Western Australia. Crop Pasture Sci 61:708-720

Ophel-Keller K, McKay A, Hartley D, Herdina CJ (2008) Development of a routine DNA-based testing service for soilborne diseases in Australia. Australas Plant Pathol 37:243-253

Robertson GI (1973) Pathogenicity of Pythium spp. to seeds and seedling roots. New Zeal J Agric Res 16:367-372

Sarathchandra SU, Watson RN, Skipp RA, Burch G, Brown JA, Cox NR (2000) Microbial pathogens and plant parasitic nematodes in pastures with declining vigour. N Z J Agric Res 43:549-558

Simpson RJ, Richardson AE, Riley IT, McKay AC, McKay SF, Ballard RA, Ophel-Keller K, Hartley D, O'Rourke TA, Li H, Sivasithamparam K, Ryan MH, Barbetti MJ (2011) Damage to roots of Trifolium subterraneum L. (subterranean clover), failure of seedlings to establish and the presence of root pathogens during autumnwinter. Grass Forage Sci 66:585-605

Skipp RA, Christensen MJ (1989) Fungi invading roots of perennial ryegrass (Lolium perenne L.) in pasture. N Z J Agric Res 32:423-431

Skipp RA, Sarathchandra U (1999) Bioindicator tests of pathogen potential and disease suppressiveness of pasture soil. In: Magarey RC (ed) Proceedings of the first Australasian soil-borne disease symposium. BSES, Brisbane, Australia, pp. 146-147

Skipp RA, Watson RN (1987) Pot experiments with pasture soils to detect soilborne pathogens of white clover and Lucerne, and effects of field application with fungicides. N Z J Agric Res 30:85-93

Skipp RA, Watson RN (1996) Disease complexes in New Zealand pastures. In: Chakraborty S, Leath KT, Skipp RA, Pederson GA, Bray RA, Latch GCM, Nutter FW (eds) Pasture and forage crop pathology: proceedings of a trilateral workshop held at the Mississippi State University, Mississippi, 10-13 April 1995. American Society of Agronomy, Crop Science Society of America, Soil Science Society of America, Wisconsin, USA, pp. 429-451

Statistics New Zealand (1999) Table S034 land use by farm type (ANZSIC) at 30 June 1999, in agricultural production survey for 
the year ended 30 June 1999. Retrieved from http://www.stats.govt. nz/searchresults.aspx?q=land use by farm type

Statistics New Zealand (2014) Key statistics Table 7.04 - value of principal exports (excluding re-exports) - SH (Qrtly-Mar/Jun/Sep/Dec). Retrieved from http://www.stats.govt.nz/infoshare/SelectVariables. aspx?pxID=d4d54d60-0748-4130-b240-1994eb954b6e

Unkovich M (2012) Nitrogen fixation in Australian dairy systems: review and prospect. Crop Pasture Sci 63:787-804

Waipara NW, Hawkins SK (2000) The effect of dairy-shed effluent irrigation on the occurrence of plant phytopathogenic Pythium species in pasture. N Z Plant Protect 53:436-440
Waipara NW, Di Menna ME, Cole ALJ, Skipp RA (1996) Potential pathogenicity of pasture plant root-colonising fungi to seedlings of legumes and grasses. Proc 49th N Z Plant Prot Conf: 212-215

Wakelin SA, van Koten C, O'Callaghan M, Brown M (2013) Physicochemical properties of 50 New Zealand pasture soils: a starting point for assessing and managing soil microbial resources. N Z J Agric Res 56:248-260

Watson RN, Mercer CF (2000) Pasture nematodes: the major scourge of white clover. Proc N Z Grassl Assoc 62:195-199

Woodfield DR, Clark DA (2009) Do forage legumes have a role in modern dairy farming systems? Ir J Agr Food Res 48:137-147 